\title{
Carbachol inhibits TNF- $\alpha$-induced endothelial barrier dysfunction through alpha 7 nicotinic receptors
}

\author{
Yu-zhen $\mathrm{LI}^{1}$, Xiu-hua LIU ${ }^{1, *}$, Fei RONG ${ }^{1}$, Sen HU², Zhi-yong SHENG ${ }^{2}$ \\ ${ }^{1}$ Department of Pathophysiology, Chinese PLA General Hospital, Beijing 100853, China; ${ }^{2}$ Laboratory of Shock and Multiple Organ \\ Dysfunction, Burns Institute, the First Affiliated Hospital of PLA General Hospital, Beijing 100037, China
}

\begin{abstract}
Aim: To test whether carbachol can influence endothelial barrier dysfunction induced by tumor necrosis factor (TNF)- $\alpha$ and whether the alpha 7 nicotinic receptor can mediate this process.

Methods: Rat cardiac microvascular endothelial cells were exposed to carbachol followed by TNF- $\alpha$ treatment in the presence or the absence of $\alpha$-bungarotoxin (an antagonist of the alpha 7 nicotinic receptor). Permeability of endothelial cells cultured on Transwell filters was assayed using FITC-albumin. F-actin was stained with FITC- phalloidin. Expression of vascular endothelial cadherin, intercellular adhesion molecule 1 (ICAM-1), phosphor-ERK1/2 and phosphor-JNK was detected using Western blot.

Results: Carbachol $(2 \mu \mathrm{mol} / \mathrm{L}-2 \mathrm{mmol} / \mathrm{L})$ prevented increase in endothelial cell permeability induced by TNF- $\alpha(500 \mathrm{ng} / \mathrm{mL})$ in a dose-dependent manner. Further, it attenuated the down-regulation of vascular endothelial cadherin and the up-regulation of ICAM-1 induced by TNF- $\alpha$. In addition, treatment of endothelial cells with carbachol decreased phosphor-ERK1/2 and phosphor-JNK. These effects of carbachol were blocked by $\alpha$-bungarotoxin $3 \mu \mathrm{g} / \mathrm{mL}$.

Conclusion: These data suggest that the inhibitory effect of carbachol on TNF- $\alpha$-induced endothelial barrier dysfunction mediated by the alpha 7 nicotinic receptor.
\end{abstract}

Keywords: carbachol; alpha 7 nicotinic receptors; endothelium; barrier function; tumor necrosis factor $\alpha$; intercellular adhesion molecule 1; ERK1/2

Acta Pharmacologica Sinica (2010) 31: 1389-1394; doi: 10.1038/aps.2010.165; published online 27 Sep 2010

\section{Introduction}

Systemic inflammatory response and vascular hyperpermeability are important for the pathophysiological basis of acute tissue injury induced by trauma, infection and shock. Proinflammatory molecules produced during trauma, infection and shock activate endothelial cells. Upon activation, endothelial cells interact with inflammatory cells. This interaction disrupts the integrity of vascular barrier function, resulting in an increase of vascular permeability ${ }^{[1]}$. Therefore, inhibition of the systemic inflammatory response and a reduction of vascular hyperpermeability are important for the prevention and treatment of acute tissue injury.

It has been documented that the cholinergic anti-inflammatory pathway is a physiological mechanism that modulates inflammatory responses. For example, nicotinic acetylcholine receptor (nAChR) agonists block tumor necrosis factor (TNF)a production by lipopolysaccharide (LPS)-stimulated mac-

\footnotetext{
* To whom correspondence should be addressed.

E-mail xiuhualiu98@yahoo.com.cn

Received 2010-04-07 Accepted 2010-08-16
}

rophages via alpha $7 \mathrm{nAChR}{ }^{[2]}$. Stimulation of the vagus nerve releases $\mathrm{ACh}$, leading to suppression of TNF-a production in vivo via alpha $7 \mathrm{nAChR}{ }^{[3]}$. Unfortunately, the use of acetylcholine and nicotine as therapeutic agents is limited by their easy hydrolysis and toxicity, respectively ${ }^{[4,5]}$.

Carbachol is an artificially synthesized cholinomimetic agonist ${ }^{[6]}$. Among its important features are stability to hydrolysis and low toxicity ${ }^{[6,7]}$. We and others have shown that carbachol inhibits the release of TNF- $\mathrm{a}^{[3]}$ and reduces the levels of TNF- $\alpha$ and interleukin-6 (IL-6) released from rat peritoneal macrophages stimulated by $\mathrm{LPS}^{[8]}$. These effects of carbachol are mediated by alpha $7 \mathrm{nAChR}$. The data indicate that carbachol has the ability to inhibit the inflammatory response. However, it is not yet clear whether carbachol is able to inhibit vascular hyperpermeability.

The endothelium is the first barrier influencing vascular permeability ${ }^{[9]}$. Barrier function of the endothelium is associated with endothelial cell permeability, cytoskeletal reorganization and expression of adherent molecules ${ }^{[10]}$. In the present study, employing an in vitro endothelial cell model, we observed the effect of carbachol on endothelial permeability, the rearrange- 
ment of F-actin and the expression of vascular endothelial cadherin (VE-cadherin) and intercellular adhesion molecule 1 (ICAM-1). Also, we tested whether alpha $7 \mathrm{nAChR}$ mediated these effects of carbachol.

\section{Materials and methods} Animals and chemicals

Male Sprague-Dawley rats weighing $80-100 \mathrm{~g}$ (1 month old) were used for EC culture. All animals were from the Experimental Animal Center, PLA General Hospital, Beijing, China. The investigation conformed to the Guide for the Care and Use of Laboratory Animals published by the US National Institutes of Health (NIH publication № 85-23, revised 1996) and approved by the local animal care and use committee. Carbachol, TNF- $\mathrm{a}$, a-bungarotoxin, collagenase I, endothelial cell growth supplement (ECGS), $\beta$-glycerophosphate, sodium orthovanadate, leupeptin, DTT, FITC-phalloidin, FITCalbumin, EDTA and HEPES were purchased from Sigma (St Louis, MO, USA). Trypsin and M199 medium were from Difco (USA). Anti-VE-cadherin, anti-ICAM-1, anti-phosphorERK1/2, and anti-phosphor-JNK antibodies were from Santa Cruz Biotechnology (USA). Newborn calf serum was from Hong Zhou Biological Research Institute (China). Other chemicals were purchased from Sigma.

Isolation and culture of rat cardiac microvascular endothelial cells and experimental protocols

Rats were anesthetized with $20 \%$ urethane by abdominal injection $(10 \mathrm{~mL} / \mathrm{kg})$. The left ventricles were fully minced and digested with $0.1 \%$ collagenase I for $6 \mathrm{~min}$ at $37^{\circ} \mathrm{C}$ in a shaking water bath. Then, $0.1 \%$ trypsin was added and incubated for $4 \mathrm{~min}$ at $37^{\circ} \mathrm{C}$. The digested solution was filtered through $100-\mu \mathrm{m}$ mesh filter, and the filtrates were collected and suspended in standard M199 medium containing $2 \mathrm{mmol} / \mathrm{L}$ L-glutamine, $100 \mathrm{U} / \mathrm{mL}$ penicillin, $100 \mu \mathrm{g} / \mathrm{mL}$ streptomycin, $25 \%$ newborn calf serum, $40 \mathrm{U} / \mathrm{mL}$ heparin and $100 \mu \mathrm{g} / \mathrm{mL}$ ECGS. Then the suspension was cultured in a humidified chamber with $5 \% \mathrm{CO}_{2}$ at $37^{\circ} \mathrm{C}$, and the medium was changed every $3 \mathrm{~d}$. The cells were characterized based on their typical cobblestone morphology and on the presence of CD31, a surface marker of microvascular endothelial cells.

All studies were performed on cells between passages three and five. Endothelial cells were exposed to concentration gradients of carbachol $(2 \mathrm{mmol} / \mathrm{L}, 0.2 \mathrm{mmol} / \mathrm{L}, 0.02 \mathrm{mmol} / \mathrm{L}, 2$ $\mu \mathrm{mol} / \mathrm{L}, 0.2 \mu \mathrm{mol} / \mathrm{L}$ ) for $15 \mathrm{~min}$. Then they were treated with TNF- $\alpha$ at a final concentration of $500 \mathrm{ng} / \mathrm{mL}$ for $24 \mathrm{~h}$. Our preliminary results showed that $500 \mathrm{ng} / \mathrm{mL}$ TNF-a consistently induces a significant increase in the permeability of endothelial cells. For experiments using the specific antagonist of the alpha 7 nicotinic acetylcholine receptor, a-bungarotoxin $(3 \mu \mathrm{g} / \mathrm{mL})$ was added to the cultures $15 \mathrm{~min}$ before carbachol administration.

Characterization of the cultured cells by cDNA microarray analysis

Total RNA was prepared from the cultured cells using TRI- zol (Invitrogen Life Technologies). cDNA probe synthesis and hybridization were made according to manufacturer's instructions (GEArray ${ }^{\mathrm{TM}} \mathrm{Q}$ serial endothelial cell biology gene array bulk kit, Bethesda, MD). The hybridization signals on the X-ray film were scanned, and the image was converted to grayscale to obtain digital number for its density. Each GEArray $^{\mathrm{TM}} \mathrm{Q}$ Series membrane was spotted with negative controls (pUC18 DNA and blanks) and housekeeping genes, including $\beta$-actin, GAPDH, cyclophilin A and ribosomal protein L13a. All raw signal intensities were corrected for background by subtracting the minimum value to avoid the appearance of negative numbers. All signal intensities were normalized to that of a housekeeping gene. The corrected and normalized signals were then used to estimate the relative abundance of particular transcripts.

\section{Permeability study of endothelial cells}

Endothelial cells were seeded on Transwell filters (Corning Costar). After reaching confluence, cells were treated according to experimental protocols. Then, $100 \mu \mathrm{L}$ FITC-albumin (1 $\mathrm{mg} / \mathrm{mL}$ ) were added gently to the upper chamber and incubated for $45 \mathrm{~min}$ in a humidified atmosphere with $5 \% \mathrm{CO}_{2}$ at $37^{\circ} \mathrm{C}$. The medium in the lower chamber was removed, and the fluorescence intensity was measured with a fluorescence spectrophotometer (excitation: $490 \mathrm{~nm}$; emission: $525 \mathrm{~nm}$ ).

\section{F-actin staining}

Endothelial cells were grown to confluence on gelatin-coated glass cover slips. After exposure to experimental conditions, endothelial cells were washed five times with PBS and fixed with $2.5 \%$ glutaraldehyde for $30 \mathrm{~min}$ at room temperature. Samples were washed three times with PBS and permeabilized with $1 \%$ Triton $\mathrm{X}$ for $10 \mathrm{~min}$ at room temperature. Then, the cells were incubated for $1 \mathrm{~h}$ at room temperature with 0.33 $\mu \mathrm{mol} / \mathrm{L}$ FITC-phalloidin. Cover slips were routinely screened by fluorescence microscopy.

\section{Western blot}

Cells were lysed at $4{ }^{\circ} \mathrm{C}$ in a lysis buffer containing $(\mathrm{mmol} / \mathrm{L})$ HEPES 20 ( $\mathrm{pH} 7.7$ ), $\mathrm{MgCl}_{2} 2.5$, EDTA 0.1, $\beta$-glycerophosphate 20, DTT 0.5, sodium orthovanadate $0.1, \mathrm{NaCl} 75$, leupeptin $4 \mu \mathrm{g} / \mathrm{mL}$, PMSF $20 \mu \mathrm{g} / \mathrm{mL}$ and Triton X-100 0.05\% (v/v). Samples were subjected to $8 \%$ SDS-PAGE and transferred to nitrocellulose membranes (Millipore Corporation, Bedford). The blotted membranes were incubated with primary antibodies, followed by a peroxidase-conjugated secondary antibody. Antigen-antibody complexes were visualized by enhanced chemiluminescence.

\section{Statistical analysis}

The results are expressed as the mean \pm SEM. For the comparison between two groups, the Student's $t$-test was employed. A one-way ANOVA was used for multiple comparisons. A value of $P<0.05$ was considered significant. 


\section{Results}

Characterization of the cultured cells by microvascular endothelial markers

cDNA microarray was used to identify the expression of microvascular endothelial markers including CD31, cadherin 5 and von Willebrand factor. As shown in Table 1, CD31, cadherin 5 and von Willebrand factor were highly expressed in the cultured cells. These data indicate that the cultured cells were microvascular endothelial cells.

Table 1. Expression of microvascular endothelial markers in the cultured cells.

\begin{tabular}{lllc}
\hline Markers & \multicolumn{1}{c}{ Full name } & $\begin{array}{c}\text { Accession } \\
\text { number }\end{array}$ & $\begin{array}{c}\text { Expression } \\
\text { intensity }\end{array}$ \\
\hline Cdh5 & Cadherin5 & NM009868 & +++ \\
CD31 & $\begin{array}{l}\text { Platelet/endothelial cell adhesion } \\
\text { molecule }\end{array}$ & NM008816 & +++ \\
Vwf & Von Willebrand factor homolog & NM011708 & +++ \\
\hline
\end{tabular}

-: non-expressing genes; +: slightly expressing genes; ++: moderately expressing genes; +++: high expressing genes.

Carbachol inhibits TNF- $\alpha$-induced increase in permeability of endothelial cells by alpha 7 nAChR

We first examined whether carbachol had a protective effect on endothelial monolayer permeability. As shown in Figure 1 , in the control group, the permeablity index of endothelial cells was $44.43 \pm 12.39\left(\mathrm{~Pa} \times 10^{-5}\right)$. In TNF-a-challenged cells, the permeablity index was significantly increased $(P<0.05$, compared with the control group). However, when carbachol was

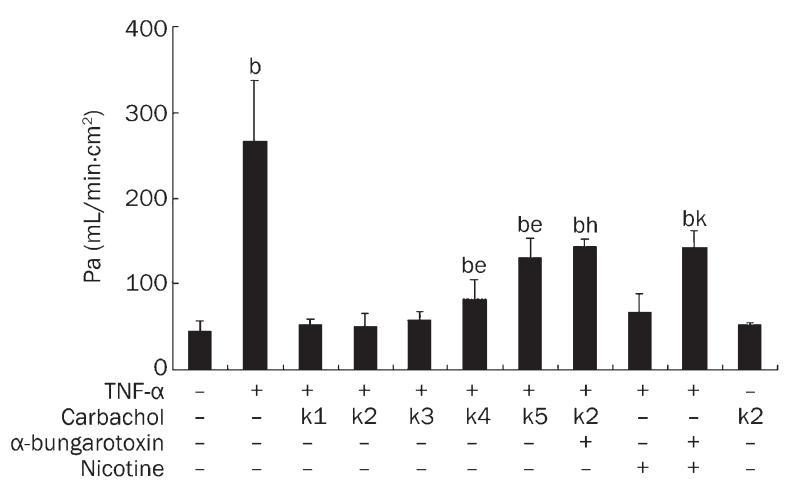

Figure 1. Carbachol inhibits TNF- $\alpha$-induced hyperpermeability of endothelial cells by alpha 7 nicotinic receptors. Endothelial cells were exposed to concentration gradients of carbachol (K1: $2 \mathrm{mmol} / \mathrm{L} ; \mathrm{K} 2$ : $0.2 \mathrm{mmol} / \mathrm{L} ; \mathrm{K} 3: 0.02 \mathrm{mmol} / \mathrm{L} ; \mathrm{K} 4: 2 \mu \mathrm{mol} / \mathrm{L} ; \mathrm{K} 5: 0.2 \mu \mathrm{mol} / \mathrm{L})$ for 15 $\mathrm{min}$. Then they were treated with TNF- $\alpha$ at a final concentration of 500 $\mathrm{ng} / \mathrm{mL}$ for $24 \mathrm{~h}$. For experiments using the antagonist of alpha 7 nicotinic receptor, $\alpha$-bungarotoxin $3 \mu \mathrm{g} / \mathrm{mL}$ was added to the cultures $15 \mathrm{~min}$ before carbachol treatment. Nicotine $(10 \mu \mathrm{mol} / \mathrm{L})$ was used as a positive control. ${ }^{\mathrm{b}} P<0.05$ vs control group; ${ }^{\mathrm{e}} P<0.05$ vs TNF- $\alpha$ group; ${ }^{\mathrm{h}} P<0.05$ vs $\mathrm{K} 2+\mathrm{TNF}-\alpha$ group; ${ }^{\mathrm{k}} P<0.05$ vs nicotine $+\mathrm{TNF}-\alpha$ group. added to the cells at concentrations of $2 \mu \mathrm{mol} / \mathrm{L}$ (K4 group) and $0.2 \mu \mathrm{mol} / \mathrm{L}$ (K5 group) followed by exposure to TNF-a, the endothelial cell-permeable indexes were lower than those of the TNF-a-challenged group $(P<0.05)$, but still higher than those of the control group $(P<0.05)$. When the cells were subjected to carbachol at concentrations of $2 \mathrm{mmol} / \mathrm{L}$ (K1 group), $0.2 \mathrm{mmol} / \mathrm{L}$ (K2 group) and $0.02 \mathrm{mmol} / \mathrm{L}$ (K3 group), respectively, before stimulation with TNF-a, there was no significant difference in permeability index between the carbachol-treated group and the control group $(P>0.05)$. It is possible that a-bungarotoxin $3 \mu \mathrm{g} / \mathrm{mL}$ antagonizes the inhibitory effect of carbachol on TNF-a-challenged hyperpermeability of endothelial cells, indicating that alpha $7 \mathrm{nAChR}$ may participate in mediating the protective effect of carbachol on endothelial monolayer permeability. In addition, we analyzed the effect of carbachol alone in the absence of TNF-a and found that carbachol alone had no effect on endothelial cell permeability ( $P>0.05$, compared with control group). These data indicate that carbachol inhibits the hyperpermeability of endothelial cells induced by TNF-a and that this effect is mediated by alpha $7 \mathrm{nAChR}$.

Carbachol prevents F-actin rearrangement of endothelial cells exposed to TNF- $\alpha$ via alpha $7 \mathrm{nAChR}$

It has been well documented that the cytoskeleton exerts a critical role in the regulation of endothelial monolayer permeability. To better understand the effects of carbachol on the cytoskeleton and the contribution of alpha $7 \mathrm{nAChR}$ activation to these effects, we next investigated the roles of carbachol and alpha $7 \mathrm{nAChR}$ in F-actin rearrangement of endothelial cells by analyzing the spatial distribution of F-actin using immunofluorescent microscopy. Under the control conditions, endothelial cells maintained their polygonal shape, with a prominent dense peripheral actin-containing cortical band (Figure 2A). TNF- $a$ induced a significant decrease in circumferential actin staining in association with a dramatic
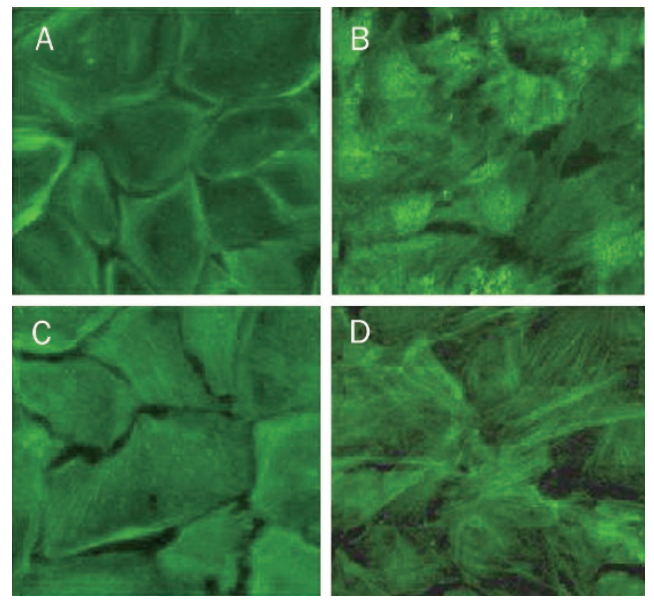

Figure 2. Carbachol prevents F-actin rearrangement of endothelial cells exposed to TNF- $\alpha$ via alpha 7 nicotinic receptors. Cells were treated as described in Figure 1. F-actin was stained with FITC-phalloidin. (A) Control; (B) TNF- $\alpha$; (C) carbachol+TNF- $\alpha$; (D) $\alpha$-bungarotoxin+carbachol+TNF- $\alpha$. 
increase in stress fiber formation, particularly in the central regions of the cells (Figure 2B). These changes were inhibited by carbachol (Figure 2C). However, blocking alpha $7 \mathrm{nAChR}$ by a-bungarotoxin, the protective role of carbachol in F-actin was abolished (Figure 2D). These data suggest that carbachol prevents F-actin rearrangement of endothelial cells exposed to TNF-a via alpha 7 nAChR.

Carbachol regulates the expression of VE-cadherin and ICAM-1 in endothelial cells by activation of alpha $7 \mathrm{nAChR}$

The effects of carbachol on the changes of TNF-a-induced VE-cadherin and ICAM-1 expression by endothelial cells were studied using Western blot. As shown in Figure 3A, VEcadherin, but not ICAM-1, was expressed in the control group of endothelial cells. When endothelial cells were exposed to TNF- $a$, the expression of VE-cadherin was down-regulated and the expression of ICAM-1 was up-regulated. Treatment of endothelial cells with carbachol attenuated the VE-cadherin down-regulation and ICAM-1 up-regulation induced by TNFa. Furthermore, the effect of carbachol on the expression of VE-cadherin and ICAM-1 was decreased when endothelial cells were subjected to a-bungarotoxin. To quantify the expression levels of VE-cadherin and ICAM-1, we used ImagePro Plus software to analyze the integrated optical density (IOD) of VE-cadherin and ICAM-1 bands. As shown in Figure

A
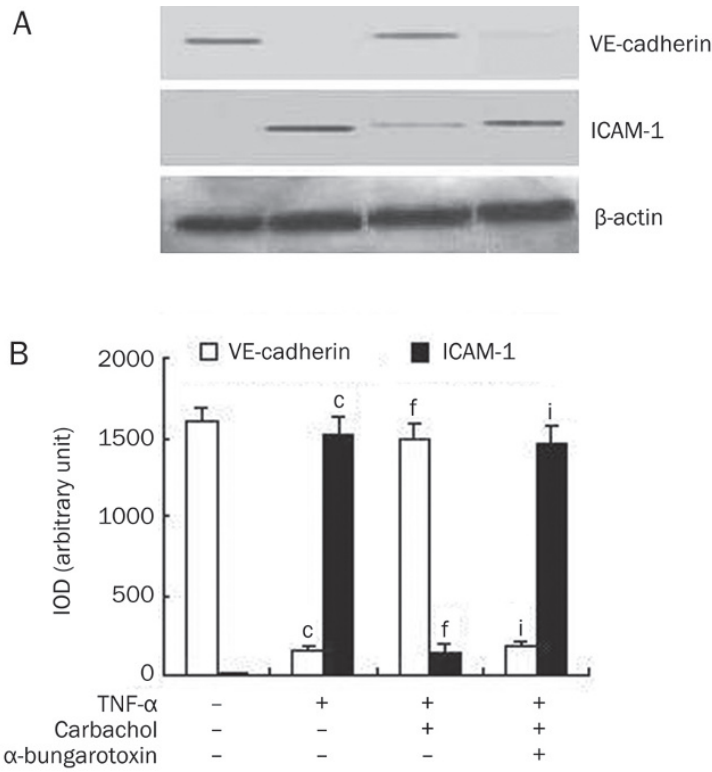

$3 \mathrm{~B}$, carbachol induced an increase in VE-cadherin expression $(P<0.001$ vs TNF-a group) and a reduction in ICAM-1 expression $(\mathrm{P}<0.001$ vs TNF-a group) in endothelial cells. However, a-bungarotoxin significantly blocked the increase of VE-cadherin expression $(P<0.001$ vs carbachol+TNF- $\alpha$ group $)$ and the reduction of ICAM-1 expression $(P<0.001$ vs carbachol+TNF- $\alpha$ group) induced by carbachol. These data indicate that carbachol regulates the expression of VE-cadherin and ICAM-1 in endothelial cells induced by TNF-a through activation of alpha $7 \mathrm{nAChR}$.

Alpha 7 nAChR mediates the inhibitory effects of carbachol on the phosphorylation of ERK1/2 and JNK in endothelial cells induced by TNF- $\alpha$

TNF- $\alpha$ can activate mitogen-activated protein kinases (MAPKs) in the signaling pathway leading to changes of VEcadherin and ICAM-1 expression ${ }^{[7,8]}$. To examine whether carbachol regulates MAPK activation induced by TNF-a, we employed Western blot to analyze the expression of phosphorERK1/2 and phosphor-JNK in endothelial cells. As shown in Figure 4, TNF-a stimulated the expression of phosphorERK1/ 2 and phosphor-JNK ( $P<0.001$ vs control group). In contrast, treatment of endothelial cells with carbachol inhibited the levels of phosphor-ERK1/2 and phosphor-JNK induced by TNF- $a(P<0.001$ vs TNF-a group). The presence of a-bungarotoxin blocked the inhibitory effect of carbachol on

A
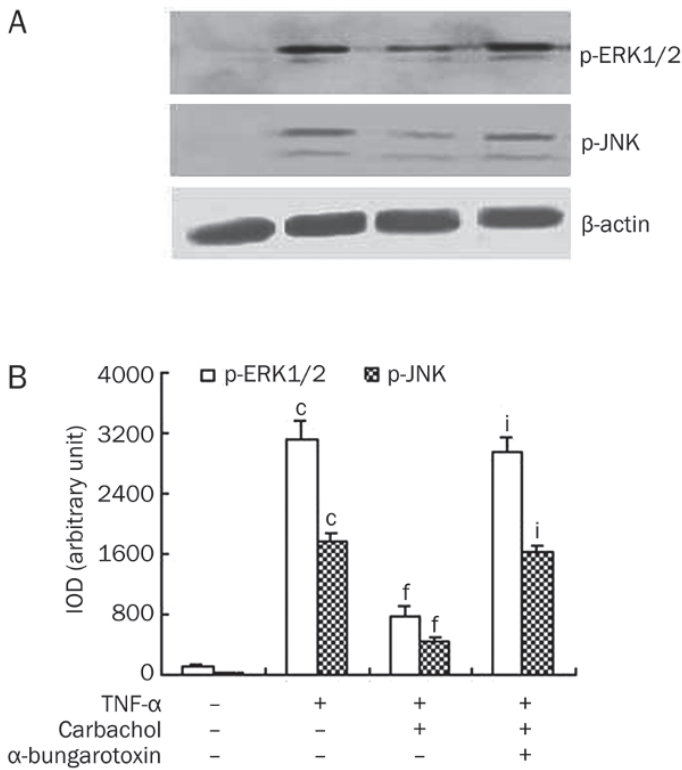

Figure 4. Alpha 7 nicotinic receptors mediate the inhibitory effects of carbachol $0.2 \mathrm{mmol} / \mathrm{L}$ on the phosphorylation of ERK1/2 and JNK in endothelial cells induced by TNF- $\alpha 500 \mathrm{ng} / \mathrm{mL}$. (A) The levels of phosphor-ERK1/2 and JNK were assessed by Western blot using protein lysates extracted from cells exposed to carbachol followed by TNF- $\alpha$ in the presence or the absence of $\alpha$-bungarotoxin $3 \mu \mathrm{g} / \mathrm{mL}$. $\beta$-Actin was used as a normalization control. (B) Integrated optical density (IOD) of ERK1/2 and JNK levels was analyzed by Image-Pro Plus software. IOD $=$ area $\times$ average density. ${ }^{\mathrm{C}} P<0.01$ vs control, ${ }^{\mathrm{f}} P<0.01$ vs TNF- $\alpha$ group, i $P<0.01$ vs carbachol+TNF- $\alpha$ group. 
the levels of phosphor-ERK1/2 and phosphor-JNK $(P<0.001$ vs carbachol+TNF-a group). These results suggest that alpha $7 \mathrm{nAChR}$ mediates the inhibitory effects of carbachol on the phosphorylation of ERK1/2 and JNK in endothelial cells induced by TNF-a.

\section{Discussion}

In the present study, we showed that carbachol can inhibit the hyperpermeability and F-actin rearrangement of endothelial cells induced by TNF-a. Also, carbachol can regulate the expression of VE-cadherin and ICAM. These effects of carbachol are mediated by alpha $7 \mathrm{nAChR}$.

The permeability of monolayer endothelial cells is controlled by the equilibrium between the endothelial cell contraction force and the intercellular contact force. This equilibrium is regulated by the cytoskeleton ${ }^{[11]}$. It has been reported that cytokines can destroy the endothelial cell cytoskeleton, cause gaps between the cells and increase transendothelial permeability $^{[12]}$. Our results show that exposure of endothelial cells to TNF-a led to the increase of endothelial cell permeability accompanied by F-actin rearrangement and stress fiber formation in endothelial cells. Intriguingly, pre-treatment of endothelial cells with carbachol prevents hyperpermeability, cytoskeletal rearrangement and the formation of stress fibers in endothelial cells. Therefore, these data suggest that carbachol suppresses the increase of endothelial permeability by protecting the endothelial cell cytoskeleton.

It has been well documented that VE-cadherin and ICAM-1, as adhesion proteins, play a pivotal regulatory role in the permeability of endothelial cells. Inhibition of VE-cadherin induces a reorganization of the actin cytoskeleton, reduces cell-cell adhesion and increases the permeability of endothelial cells $^{[13]}$. Also, overexpression of ICAM-1 causes alteration of the actin cytoskeleton-endothelial junction, thereby inducing the hyperpermeability of endothelial cells ${ }^{[14]}$. It has been reported that TNF-a induces an increase in the permeability of endothelial cells by decreasing VE-cadherin protein expression and stimulating ICAM-1 protein expression ${ }^{[13,15]}$. In the present study, we found that TNF-a down-regulates VE-cadherin expression and up-regulates ICAM-1 expression. Our observation is consistent with previously reported results. Further, we showed that carbachol inhibits the effect of TNF-a on the expression of VE-cadherin and ICAM-1. It seems that carbachol inhibits the hyperpermeability of endothelial cells by regulating the expression of VE-cadherin and ICAM-1.

MAPKs are highly conserved serine/threonine kinases that are activated in response to a wide variety of stimuli. TNF-a inhibits VE-cadherin expression and stimulates ICAM-1 expression through the activation of ERK1/2 and JNK and, subsequently, increases the permeability of endothelial cells $^{[13,16]}$. In the present study, we showed that carbachol inhibits ERK1/2 and JNK phosphorylation induced by TNFa. It is possible that carbachol exerts its function by ERK1/2 and JNK pathways. However, it is necessary to determine the kinase phosphorylation sites and whether the inhibitors of ERK1/2 and JNK block the effects of carbachol.
We have previously shown that alpha $7 \mathrm{nAChR}$ mediates the anti-inflammatory effect of carbachol ${ }^{[8]}$. Also, others have reported that administration of acetylcholine inhibits LPSinduced TNF-a release by a reduction in phosphorylation of MAPKs. This inhibitory effect of acetylcholine is blocked by a-bungarotoxin, a specific antagonist of alpha $7 \mathrm{nAChR}{ }^{[17]}$. Our present study indicates that a-bungarotoxin blocks the effect of carbachol on ERK1/2 and JNK activation and the expression of VE-cadherin and ICAM-1 in endothelial cells. Additionally, a-bungarotoxin blocks the inhibitory effect of carbachol on the permeablity index of endothelial cells and F-actin rearrangement induced by TNF-a. Our findings suggest that, similar to anti-inflammatory effects, the inhibitory effect of carbachol on endothelial barrier dysfunction is also mediated by alpha $7 \mathrm{nAChR}$.

The present study provides evidence that carbachol improves endothelial barrier dysfunction induced by TNF- $a$ and that alpha $7 \mathrm{nAChR}$ mediates the process. Because endothelial barrier dysfunction is crucial for the pathophysiological basis of acute tissue injury, our study implies that carbachol may have therapeutic potential for acute tissue injury.

\section{Acknowledgements}

This work was supported by the Special Foundation of the 11th Five-Year Plan for Military Medical Project (№ 06Z055).

\section{Author contribution}

Xiu-hua LIU, Sen HU, and Zhi-yong SHENG designed research; Yu-zhen LI and Fei RONG performed research; Yuzhen LI analyzed data and wrote the paper.

\section{References}

1 Norman MU, Lister KJ, Yang YH, Issekutz A, Hickey MJ. TNF regulates leukocyte-endothelial cell interactions and microvascular dysfunction during immune complex-mediated inflammation. Br J Pharmacol 2005; 144: 265-74.

2 Wang H, Yu M, Ochani M, Amella CA, Tanovic M, Susarla S, et al. Nicotinic acetylcholine receptor alpha7 subunit is an essential regulator of inflammation. Nature 2003; 421: 384-8.

3 Borovikova LV, Ivanova S, Zhang M, Yang H, Botchkina Gl, Watkins LR, et al. Vagus nerve stimulation attenuates the systemic inflammatory response to endotoxin. Nature 2000; 405: 458-62.

4 Bourne Y, Radic Z, Sulzenbacher G, Kim E, Taylor P, Marchot P. Substrate and product trafficking through the active center gorge of acetylcholinesterase analyzed by crystallography and equilibrium binding. J Bio Chem 2006; 281: 29256-67.

5 Benowitz NL. The human pharmacology of nicotine. In: Capell HD, Glaser FB, Israel Y, Kalant H, Schmidt W, Sellers EM, et al, editors. Research advances in alcohol and drug problems; $V$ 9. New York: Plenum Press; 1986. p 1-52.

6 Taggart DP, Dipp M, Mussa S, Nye PC. Phenoxybenzamine prevents spasm in radial artery conduits for coronary artery bypass grafting. Thorac Cardiovasc Surg 2000; 120: 815-7.

7 Béla H, Petra O, Zoltán B. Endothelial NOS-mediated relaxations of isolated thoracic aorta of the C57BL/6J mouse: a methodological study. J Cardiovasc Pharmacol 2005; 45: 225-31.

8 Hu S, Zhou GY, Lü Y, Song Q, Zou XF, Sheng ZY. Effects of carbachol on inflammatory cytokine releases from rat peritoneal macrophages 
induced by lipopolysaccharide and its receptor. Chin Pharmacol Bull 2007; 23: 1161-5.

9 Vestweber D, Broermann A, Schulte D. Control of endothelial barrier function by regulating vascular endothelial-cadherin. Curr Opin Hematol 2010; 17: 230-6.

10 Zeiller C, Mebarek S, Jaafar R, Pirola L, Lagarde M, Prigent AF, et al. Phospholipase D2 regulates endothelial permeability through cytoskeleton reorganization and occludin downregulation. Biochim Biophys Acta 2009; 1793: 1236-49.

11 Benz PM, Blume C, Moebius J, Oschatz C, Schuh K, Sickmann A, et al. Cytoskeleton assembly at endothelial cell-cell contacts is regulated by alphall-spectrin-VASP complexes. J Cell Biol 2008; 180: 205-19.

12 Seynhaeve AL, Vermeulen CE, Eggermont AM, ten Hagen TL. Cytokines and vascular permeability: an in vitro study on human endothelial cells in relation to tumor necrosis factor-alpha-primed peripheral blood mononuclear cells. Cell Biochem Biophys 2006; 44: 157-69.
13 Nwariaku FE, Liu Z, Zhu X, Nahari D, Ingle C, Wu RF, et al. NADPH oxidase mediates vascular endothelial cadherin phosphorylation and endothelial dysfunction. Blood 2004; 104: 3214-20.

14 Sumagin R, Lomakina E, Sarelius IH. Leukocyte-endothelial cell interactions are linked to vascular permeability via ICAM-1-mediated signaling. Am J Physiol Heart Circ Physiol 2008; 295: H969-H977.

15 Javaid K, Rahman A, Anwar KN, Frey RS, Minshall RD, Malik AB. Tumor necrosis factor- $\alpha$ induces early-onset endothelial adhesivity by protein kinase $\mathrm{C}$-dependent activation of intercellular adhesion molecule-1. Circ Res 2003; 92: 1089-97.

16 Nwariaku FE, Chang J, Zhu X, Liu Z, Duffy SL, Halaihel NH, et al. The role of p38 map kinase in tumor necrosis factor-induced redistribution of vascular endothelial cadherin and increased endothelial permeability. Shock 2002; 18: 82-5.

17 Shytle RD, Mori T, Townsend K, Vendrame M, Sun N, Zeng J, et al. Cholinergic modulation of microglial activation by alpha 7 nicotinic receptors. J Neurochem 2004; 89: 337-43. 